\title{
JoÃo do Rio, Alcântara Machado, Alberto Cavalcanti: entre o filme De PAPEL E A CRÔNICA DE CELULOIDE
}

Jõ̃o do RIo, Alcântara Machado, Alberto Cavalcanti: BETWEEN PAPER FILM AND CELLULOID NEWSPAPER

\section{Miriam Gárate}

Universidade Estadual de Campinas, Unicamp

Campinas, SP, Brasil

Palavras-chave: crônica urbana; literatura; cinema documental; início do século XX.

Keywords: urban chronicle; literature; documentary cinema; early 20 th century

Palabras llave: crónica urbana; literatura; cine documental; principios del siglo XX.

\section{Resumo}

O presente artigo visa examinar a relação de mão dupla entre crônica jornalístico-literária e cinema documental, adotando como corpus de análise Cinematógrafo. Crônicas cariocas (1909) de João do Rio, Pathé Baby (1926) de Antônio Alcântara Machado e Rien que les heures (1926) de Alberto Cavalcanti.

\section{Abstract}

This article aims to examine the two-way relationship between literary journalistic chronicles and documentary cinema through the analysis of the following corpus: Cinematógrafo: Crônicas cariocas, by João do Rio, Pathé Baby, by Antônio Alcântara Machado, and Rien que les heures (1926), by Alberto Cavalcanti.

\section{Resumen}

El presente artículo se propone examinar la relación de mano doble existente entre crónica periodístico-literaria y cine documental, adoptando como corpus de análisis Cinematógrafo. Crônicas cariocas (1909), de João do Rio, Pathé Baby (1926), de Antônio Alcântara Machado, y Rien que les heures (1926), de Alberto Cavalcanti.
Desde as primeiras projeçóes públicas do cinematógrafo, travou-se uma relação de mão dupla entre expressóes da imprensa periódica e formatos do novo espetáculo. O sintoma mais visível desse fenômeno é a transferência de nomenclaturas, sua migração de um âmbito a outro. Por um lado, no início do século XX numerosos artigos e colunas adotam títulos tais como Kinetoscópio, Cinematógrafo, Vitascópio, Cinema da vida; por outro, à medida que o espetáculo cinematográfico se desenvolve surgem denominaçóes 
como "atualidades", "cine-revista" e "cinejornal" para dar título a diversas formas fílmicas. Se essas realizaçóes podem ser consideradas uma espécie de correlato cinematográfico da imprensa periódica e compartilham com ela algumas características (funçóes informativas, pedagógicas, de propaganda), a crônica, esse gênero jornalístico e literário que ganha particular força na virada do século XX, tende a se tornar, com frequência, um cinematógrafo, para recorrer ao título escolhido por João do Rio.

Recapitulo brevemente alguns aspectos relativos ao processo de modernização e especialização da imprensa que tem lugar nas últimas décadas do século XIX, na América Latina - o processo se deu antes, de modo mais extenso e intenso, na Europa e nos Estados Unidos. Modernização e especialização da imprensa supõem o desenvolvimento de um novo tipo de discurso, a notícia, de um novo profissional, o repórter, e implicam uma reconfiguração do literário e do exercício da literatura no interior do espaço jornalístico. Nessa cena, a crônica se constitui como um lugar intermediário, no qual os escritores integrados ao novo mercado jornalístico ensaiam, exercitam e experimentam seu estilo ou, em outras palavras, no qual os escritores fazem literatura. De que forma? Sobre-escrevendo (escrevendo sobre) as notícias que o próprio jornal dá a ler,* adotando a retórica da viagem ou do passeio, ainda que não sejam repórteres nem se desloquem a outras cidades, ${ }^{*}$ renarrativizando (relacionando) aquilo que se postula simultaneamente como fragmentário: a cidade e o jornalismo modernizados.* Daí algumas características apontadas por Candido com respeito a esse gênero "filho do jornal e da era da máquina, concebido para a publicação efêmera, em veículo transitório", * que, no entanto, conquistou direito de cidadania na república das letras: resgate e proliferação do instante, do passageiro, do dado ou a informação menor capaz de pôr em evidência algum aspecto singular do ambiente; estrutura compositiva errática e "frouxa". Grande parte da literatura que interessa ainda hoje foi praticada nessa fronteira, nesse lugar híbrido que, não obstante, teve sua heterogeneidade e transitoriedade reconvertidas com frequência ao modelo da obra e segundo os ditados do livro. Talvez devêssemos considerar esse processo de reconversão como uma renarrativização de segundo grau: a crônica confere uma feição narrativa a esse artefato linguístico denominado notícia, o volume de crônicas reúne pela segunda vez a heterogeneidade tópica e material das crônicas. É esse o caso
* (RAMOS, Julio. Desencontros da modernidade na América Latina. Literatura e política no século XIX (1989). Belo Horizonte: UFMG, 2008: 128.)

* (RAMOS, Julio. Desencontros da modernidade na América Latina. Literatura e política no século XIX (1989), op. cit.: 124.)

* (CANDIDO, Antonio. "A vida ao rés-do-chão". In: CANDIDO, Antonio et al.; A crônica. O gênero, sua fixação e suas transformações no Brasil. Campinas: Unicamp; Rio de Janeiro: Fundação Casa de Rui Barbosa, 1992: 14.)

* (Ibidem: 145.) 
* (JOÃO do RIO. Cinematógrafo das letras. Crônicas Cariocas. Rio de Janeiro: $\mathrm{ABL}$, 2009: 4.) de Cinematógrafo, conjunto de crônicas cariocas relativas aos anos de 1904-1908 compiladas e republicadas por João do Rio um ano depois. ${ }^{1} \mathrm{Na}$ passagem abaixo citada, o espetáculo cinematográfico desponta como paradigma, marco, princípio ordenador e protocolo de leitura, já que o prefácio e o epílogo das crônicas as apresentam ao leitor como uma sucessão de fitas, nas quais se alternam a flânerie pelos redutos chics da cidade e por subúrbios marginais, a crítica de costumes, de espetáculos à la mode e de entretenimentos populares, a observação satírica sobre as falsas notícias difundidas nos jornais ou sobre a atualidade política:

Uma fita, outra fita, mais outra... Não nos agrada a primeira? Passemos à segunda. Náo nos serve a serve a segunda? Para diante entāo! Há fitas cômicas, há fitas serias, há melancólicas, picarescas, fúnebres, alegres - algumas preparadas por atores notáveis para dar a reproduçáo idealizada de qualquer fato, outras tomadas nervosamente pelo operador, à passagem do fato. Umas curtas, outras long... Com pouco tens a agregaçáo de vários fatos, a história ao vivo, a vida da cidade numa sessão de cinematógrafo [...] A crônica evolui para a cinematografia. Era reflexão e comentário, o reverso desse sinistro animal de gênero indefinido a que chamam: o artigo de fundo. Passou a desenho e a caricatura. Ultimamente era fotografia retocada mas sem vida. Com o delírio apressado de todos nós, é agora cinematográfica - um cinematógrafo das letras, o romance da vida do operador no labirinto dos fatos, da vida alheia e da fantasia - mas romance em que o operador é personagem secundário arrastado na torrente dos acontecimentos. ${ }^{* 2}$

\footnotetext{
${ }^{1}$ No relatório de doutorado referente a pesquisa desenvolvida sob minha orientação, e baseando-se nas informações constantes no trabalho de João Carlos Rodrigues (João do Rio: Catálogo Bibliográfico. Rio de Janeiro: Secretaria Municipal de Cultura. Departamento Geral de Documentação e Informaçáo Cultural, Divisão de Editoraçáo, 1994), Danielle Crepaldi Carvalho registra que: "Cinematógrafo: crônicas cariocas é a compilação de um conjunto de crônicas publicadas pelo escritor nos jornais cariocas A Notícia e Gazeta de Notícias, entre 1904 e 1909, em séries cronísticas ou de modo avulso, com os pseudônimos de "João do Rio" ou "Joe". Apenas seis das 45 crônicas são oriundas da sessão homônima e, ainda assim, de partes dela. $\mathrm{O}$ excerto da crônica que faz parte da introdução do volume é publicada n'A Notícia em agosto de 1909 , quando da inauguração na capital do Odeon: "o Municipal dos cinematógrafos", diz o cronista - traçando um paralelo entre aquela elegante casa e o Teatro que a cidade recém-inaugurara”. (mimeo: 51.)

${ }^{2}$ Transcrevo o epílogo que dá continuidade a esta encenação encerrando a sessão de Cinematógrafo: "Ao leitor: E tu leste, e tu viste tantas fitas... Se gostaste de alguma, fica sabendo que foram todas apanhadas ao natural e que mais não são senáo os fatos de um ano, as ideias de um ano, os comentários de um ano - o de 1908, apanhados por um aparelho fantasista e que nem sempre apanhou o bom para poder sorrir à vontade e que nunca chegou a muito mau para não fazer cho-
} 
Embora o texto se inscreva num horizonte pré-modernista no referente às estratégias da escrita, como oportunamente sublinhou Flora Süssekind;* embora o mesmo ocorra em relação ao espetáculo cinematográfico adotado como modelo (a passagem remete claramente ao cinema de atraçóes), a série de figuraçóes óticas propostas nesse prefácio acena em direção a uma nova escrita, anunciando as crônicas urbanas que pouco depois serão tramadas com palavras ou com imagens filmadas. Em ambos os casos, o turbilhão dos acontecimentos, o fluir vário do tempo/movimento que instaura a cidade e capta o operador serão submetidos a procedimentos comparáveis (voltarei a esta questáo). Tẫo significativo quanto o vislumbre das crônicas como fitas ou do conjunto como uma prolongada sessão de cinema é, portanto, a percepção do próprio cronista como operador e, mais ainda, da imagem da mente como um cinematógrafo:

Ao demais, se a vida é um cinematógrafo colossal, cada homem tem no crânio um cinematógrafo de que o operador é a imaginação. Basta fechar os olhos e as fitas correm no cortical com uma velocidade inacreditável. Tudo quanto o ser humano realizou, não passa de uma reprodução ampliada da sua própria máquina e das necessidades instintivas dessa máquina. O cinematógrafo é uma delas.*

Curiosamente, próximo do postulado que Edgar Morin desenvolveria anos mais tarde em seu clássico Le cinéma ou l'homme imaginaire, ${ }^{*}$ o cinematógrafo funciona, aqui, como dispositivo que molda e expressa o sujeito, como figura de sua constituição psíquica - indelevelmente marcada pela coexistência de arcaísmo e modernidade, de acordo com o pensador francês; caracterizada por uma percepção distraída e fragmentária em sintonia com as transfor-

rar. A sabedoria está no meio termo da emoção. Vale”. (JOÃO do RIO. Cinematógrafo das letras. Crônicas Cariocas, op. cit.: 272.) A complementariedade entre a retórica da viagem enquanto traço recorrente da crônica literária da virada do século e o espetáculo cinematográfico do mesmo período enquanto viagem pode ser lida numa crônica de Olavo Bilac, publicada na Gazeta de Notícias de 3/11/1907 "Venho escrever esta "Crônica" depois de uma longa excursão. Estou derreado, tenho dores nos rins e nas pernas, doem-me os olhos de ter visto tanta cousa, dói-me o cérebro de haver pensado tanto. A minha viagem durou duas borás: entretanto, em táo escasso tempo achei meio de ver meio mundo: estive em Paris, em Roma, em Nova York, em Miláo; vi Cristo nascer e morrer; desci ao fundo de uma mina de carvão". (BILAC, Olavo. "Moléstia da época". In: Vossa insolência. Crônicas. Org. de Antonio Dimas. Sáo Paulo: Companhia das Letras, 1996: 195.) Sobre este tema ver artigo meu. (GÁRATE, Miriam. V"Três escritores vão ao cinematógrafo. Crônica jornalística e retórica da viagem em Luis Urbina, Olavo Bilac e Ramón López Velarde”. Caracol, 3, 2012: 134-152.)
* (SÜSSEKIND, Flora. Cinematógrafo das letras. São Paulo: Companhia das Letras, 1987)

* (JOÃO do RIO. Cinematógrafo das letras. Crônicas Cariocas, op. cit.: 5)

*(MORIN, Edgar. Le cinéma ou l'homme imaginaire. Paris: Minuit, 1956.) 
maçóes em curso, de acordo com a leitura benjaminiana de Süssekind. ${ }^{3}$ Mas, ainda que essa aproximação ao cinema comporte em teoria a irrupção de novas formas de escrita, para a ensaísta brasileira se trata de um fenômeno que não chega a se concretizar na produção de João do Rio nem na de seus coetâneos:

[...] é como se o cronista (João do Rio) assistisse, com certo deslumbramento, à constituição de um novo horizonte técnico e tentasse imaginar relaçóes possíveis com ele. E, da mesma maneira que sonha, numa crônica de 1910, com um futuro "jornal Eletro Rápido", projeta essa imagem de um "cinematógrafo das letras" como sinônimo de uma literatura que operasse como os modernos aparelhos de produção e reprodução de imagens técnicas. Diante dos novos maquinismos, a reaçáo, meio no susto, numa primeira instância, é, pois, de imitação. Não parece possível ainda a João do Rio reelaborar criticamente esse influxo técnico. É possível somente uma espécie de flirt rápido com ele. Situaçáo que não seria, no entanto, exclusividade de Paulo Barreto (João do Rio) [...]. Na verdade, a maior parte dos autores da virada do século e dos anos 10-20 pareceu hesitar diante do horizonte técnico em configuração. Sem chegar, no período, a estabelecer em geral ligaçóes mais perigosas, e com melhores resultados estéticos, com tais artefatos modernos [...]. Montagens e cortes passariam a invadir, de fato, a técnica literária com a prosa modernista”.*

Exemplos dessa técnica literária decididamente modernista? Os romances Memórias sentimentais de João Miramar (1924) e Serafim Ponte Grande (1933), de Oswald de Andrade, ou Amar, verbo intransitivo (1927), de Mário de Andrade, entre outros. No que se refere à crônica, Pathé Baby, de Antônio de Alcântara Machado, texto duplamente exemplar.

\footnotetext{
${ }^{3}$ Cito: "Cinematógrafo no crânio: com isso João do Rio parece representar o triunfo de uma percepção distraída e fragmentária por parte de leitores e espectadores. 'A recepção através da distração, que se observa crescentemente em todos os domínios da arte e constituí o sintoma de transformaçóes profundas nas estruturas perceptivas', afirmava Benjamin, 'tem no cinema o seu cenário privilegiado'. João do Rio, a seu modo, se deu conta dessas transformaçóes. 'Interessante aquela fita, dizes. E dois minutos depois não te lembras mais', lê-se no Cinematógrafo. [...] [O] próprio cinematógrafo trabalharia com essa possibilidade de descarte, com uma recepção desatenta, com a superfície [...]. E o escritor carioca incorpora justamente esse passar-sem-deixar-marca. O que se percebe, por exemplo, nos seus personagens, quase-figurinos de revista, propositadamente sem fundo, só-superfície...” (SÜSSEKIND, Flora. Cinematógrafo das Letras, op. cit.: 46.)
} 
Operar como os modernos aparelhos de produçáo e de reprodução de imagens técnicas. Operar com eles. Trazê-los para o campo de uma escrita que assume em vários registros, com o auxílio de diversas linguagens e procedimentos, o cinema como paradigma. É em torno dessas premissas que se estrutura Pathé Baby, ${ }^{*}$ um livro dado a ver e a ler desde o título como a projeçáo de imagens captadas pelo operador-cronista graças a uma das câmeras portáteis mais populares do período.

Alguns esclarecimentos indispensáveis: Pathé Baby passa por um processo de reformatação análogo ao sofrido por Cinematógrafo, de João do Rio. Em 1925, as notas de viagem de Alcântara Machado são publicadas no Jornal do Comércio, de São Paulo, órgão com o qual o jornalista vinha colaborando desde 1921. Em 1926, uma seleção dessas notas parcialmente reescritas, reeditadas (montadas?) em alternância com as ilustraçóes de Paim Vieira (1895-1988) e prefaciadas por Oswald de Andrade são relançadas como livro. ${ }^{4}$ Desde o início, a capa, a primeira página e o Programalíndice instauram um pacto análogo ao que proporá o chileno Vicente Huidobro em seu Cagliostro. Novela filme (1921-3): "Imagine o leitor que não comprou este livro em uma livraria, mas que comprou um ingresso para entrar no cinematógrafo. Assim, caro leitor, você não está saindo de uma livraria, mas entrando no cinema".*

No caso de Alcântara Machado, o pacto é instituído tanto a partir da dimensão gráfica, que projeta o título na tela e dá a ver (ouvir) a orquestra na metade inferior da página, como a partir do registro verbal: as crônicas se subdividem em partes, como consta no Programalíndice; cada uma dessas partes ou episódios, como são denominados no corpo das crônicas, recebe um tratamento que aproxima os enunciados do letreiro ou do intertítulo - expressões breves que situam o espaço e o tempo ("Meia noite, Boulevard des Capucines"), sintetizam açóes ("Ida, volta"), suscitam curiosidade ("O lusitano do compartimento vermelho").

\footnotetext{
${ }^{4}$ Devido à exigência por parte da plataforma SciELO de autorização expressa dos detentores de direitos, as imagens da edição fac-similar aqui citada não puderam ser reproduzidas. O leitor pode procurá-las tanto nessa edição da Imprensa Oficial/Arquivo do Estado, de 1982, como na edição posterior, também fac-similar, de 2002: MACHADO, Antonio de Alcântara. Pathé Baby. Belo Horizonte-Rio de Janeiro: Livraria Garnier, 2002
}

* (MACHADO, Antonio de Alcântara. Pathé Baby (1926). São Paulo: Imprensa Oficial/Arquivo do Estado, 1982.)

* (HUIDOBRO, Vicente. Cagliostro. Novela filme (19213). Santiago de Chile: Editora Universitaria, 1997: 41.) 
* (In: MACHADO, Antonio de Alcântara. Pathé Baby (1926), op. cit.: 13.)

* (MACHADO, Antonio de Alcântara. "Las Palmas; 1. Apresentação". In: Pathé Baby (1926), op. cit.: 19.)

* (MACHADO, Antonio de Alcântara. "Milão: 1. Compêndio urbano". In: Pathé Baby (1926), op. cit.: 87.)

* (MACHADO, Antonio de Alcântara. "Milão: 3. Notabilidades amestradas". In: . Pathé Baby (1926), op. cit.: 88-9.)

* (MACHADO, Antonio de Alcântara. "Assis". In: op. cit.: 162.)
Bilhete de ingresso e programa na mão, o leitor entra na sala e enquanto espera o início da sessão lê a ouverture (prefácio) de Oswald de Andrade. Se o primeiro pacto (o primeiro limiar) instaura o espetáculo cinematográfico como horizonte de recepção, a ouverture define o gênero ao qual a obra pertence e garante a sua qualidade. Para Oswald de Andrade, Alcântara Machado é membro da geração "mais desenvolta, segura e perigosa" que veio depois da "Philips modernista"; seu Pathé Baby é literatura de reportagem:

Vc apossou-se sem espanto temperatura ocasional cada gente cada país. Por todo seu livro concordância amável realmente Europa gostosa ridícula. Pathé Baby é reportagem. Como mudam tempos diria Marquez Maricá pensando Joáo do Rio. De fato da tolice amável esse seu malogrado amigo à segurança seu estilo seu modo acertar vão diversos séculos. Brasil país milagres acrescentaria Marquez ignorando grande literatura nossa época é reportagem.*

Concluída a ouverture, prorrompe a orquestra e se põe a rodar a primeira fita: "Puerto de la Luz é o vestíbulo arenoso. Comprometedor, A cidade, que o mar e a montanha limitam, fica distante. MODERE UD LA MARCHA HASTA $15 \mathrm{kls}$ por hora”. * O espetáculo proposto ao longo de mais de duzentas páginas convoca o cinematográfico em vários níveis. No referente à escrita, evidenciando seu alto grau de penetração na vida cotidiana e no imaginário social, o cinema comparece como motivo temático: "Italianas lindas. A qualquer hora. Alugáveis ou não. Olhos de tragédia. Atitudes cinematográficas de mulher fatal"; "Na Piazza di S Fedele, ao lado de Manzoni, o homenzinho comanda os pombos: - Mussolini! Mussolini. Destacando-se do grupo inquieto, que bica o chão, $\mathrm{M}$ agita as asas e vem receber a sua bolota de pão... - Adesso, Maria Melato!";* "Cimbaue, Giotto e discípulos enchem a Chiesa Superiore. A monotonia da arte conseguida. Nem um tico mal feito. Enjoa até. A cripta, sim, é uma indecência estupenda do século XIX. - Sembra la salla d'aspetto di um cinematografo".* Ocasionalmente, os motivos da cidade como set e dos percalços da rodagem também se fazem presentes:

Nos jardins verdes do Alcázar, a Paramount Pictures fabrica uma película árabe. Nas janelas do Pabellón de Carlos V sultanas de pele loira e olheiras azuis fumam Ariston.

Entre as colunas de mármore branco, o diretor toma chá e morde o cachimbo. Albornozes. Sandálias, Punhais. Véus. 
Para duas objetivas, a favorita trai o sultão de barbaças com o jovem cheik. Mas o espião entra.

$\mathrm{O}$ diretor berra:

- No!

O espião entra de novo.

- No!

O espião entra pela terceira vez.

- No!

O eunuco do serralho é pai da heroína, que nasceu em Chicago.

O sultão, a um lado, foxtrotea e canta:

I want to be...

$\mathrm{O}$ espiāo entra pela quarta vez

- Yes! $^{*}$

Mas o cinema constitui sobretudo um paradigma de composição tendente a modelar cada enunciado como sucedâneo de uma tomada ou plano e a organizar a sucessão de planos/enunciados segundo a lógica da montagem: "Trilhos, trilhos, trilhos. Discos verdes, discos vermelhos. Lanternas. Sinais. Avisos. Letreiros. Trens parados. Trilhos. Postes. Guindastes. Locomotivas fumegantes. Arrabaldes tranquilos. Automóveis. Estaçôes pequeninas de nomes enormes. Fumaça. Trilhos. Rapidez do trem que voa. Ruído".* Como é possível constatar, a justaposição paratática de sintagmas nominais, sua brevidade, a repetiçâo sucessiva e a alternada de alguns deles (vias) buscam propiciar um efeito análogo ao da sucessáo de planos curtos, tentam criar um ritmo verbal (imagético) que a montagem acelerada das sinfonias urbanas vanguardistas perseguirá no plano estritamente fílmico (basta pensar no início de Berlim, a sinfonia de uma grande cidade, de Ruttmann).

$\mathrm{Na}$ realização desse "documentário" (dessa reportagem, segundo a denominação oswaldiana), o cronista/viajante/escritor/ cameraman circula com sua Pathé Baby e escreve/filma as tomadas "do natural" (d'après nature), segundo expressão consagrada à época. O estúdio, a cenografia artificial e artificiosa, a maquiagem de seres e de objetos são abolidos em benefício da captação "direta". O estilo não marcado se torna um significante de base para a nova arte literária. Daí o elogio professado a Alcântara Machado e à sua prosa: trata-se de um escritor que escreve sem literatura. ${ }^{5}$ Evidente-

\footnotetext{
5 "O Sr. Alcântara Machado é um singular temperamento de escritor. Com uma sensibilidade pura, com um agudo espírito de observação anda pela vida com uns grandes olhos de 'Kodak' fixando com exatidáo as coisas que encontra no seu caminho. Não deforma nem enfeita. Fixa as pessoas e as coisas como elas são. Mas ...alma sempre comovida e às vezes também irônica diante dos espetáculos da vi-
}

* (MACHADO, Antonio de Alcântara. "Sevilha, 2. Cinematografia". Em: MACHADO, Antonio de Alcântara. Pathé Baby (1926), op. cit.: 190-1.)

* (MACHADO, Antonio de Alcântara. "De Cherbourg a Paris: 4: chiuú!". In: (1926), op. cit.: 43.) 
* (XAVIER, Valêncio. "Cinema escrito". Revista Cult, 47, jun 2001: 62.) mente, a marca ou significante do trabalho artístico não desapareceu; transferiu-se do ornato pré-modernista, de seu vocabulário luxuoso, de suas complexas construçóes sintáticas, para uma estética da expressão direta, econômica, mas especialmente para o trabalho realizado com o corte e a justaposição, com a montagem que se processa entre as palavras. ${ }^{6}$

A essas operaçóes no âmbito verbal se soma uma montagem alternada entre escrita e ilustração, dando lugar a uma narrativa dupla (ou tripla) que, de acordo com Valêncio Xavier, "corre simultaneamente em duas pistas":* o filme escrito por Alcântara Machado e o ilustrado por Paim Vieira, que por sua vez se bifurca no desenho-fita projetado na tela (metade superior da página) e no desenho-relato acerca das peripécias da orquestra, cujos executantes abandonam a sessão um após outro (metade inferior da página).

$\mathrm{O}$ desenho-fita projeta sobre a parte superior da página uma espécie de síntese visual, antecipando dessa forma o filme escrito. Nesse caso, ilustração e palavras olham desde suas materialidades específicas em direção às "mesmas" imagens, oferecem-nas alternativamente para que o olho-mente do leitor as veja/leia. É o que ocorre, por exemplo, com o apertado e multifacetado desenho-fita relativo a Paris, que aduna um conjunto de motivos presente em diversas passagens da "super especial película de grande metragem" (Programa) escrita: "Place de l'Etoile. Em torno do Arco do Triunfo magotes de automóveis giram. As avenidas são doze bocas de asfalto que comem gente e veículos, vomitam gente e veículos, Insaciáveis.

da... São Paulo está todo nos contos do Sr Alcântara Machado. Direto, simples, claro, o Sr. Alcântara Machado é uma exceção entre nossos prosadores. Escreve sem literatura" (O jornal, Rio de Janeiro, 3 de julho de 1927, s/a; In: MACHADO, Antonio de Alcântara. Obras, volume I. LARA, Cecilia org.; Rio de Janeiro: Civilização Brasileira; Brasilia: INL, 1983: 279-280).

${ }^{6}$ Referindo-se ao manifesto de Klaxon e ao interesse dos novos escritores pelo cinema, Ismail Xavier afirma: "A preocupação com o fenômeno cinematográfico não ficará reduzida aos elogios do manifesto. Exceção feita do número quatro, em todos os outros haverá matéria sobre cinema. Os líderes da renovação literária terão nele um elemento motivador de discussóes e críticas, chegando a colocá-lo como um referencial útil na explicação de Oswald em Os condenados [...]. O modelo de organizaçáo dos filmes é utilizado como matriz para, de forma sintética, caracterizar um estilo literário marcado pelo uso do "subentendimento", como diriam os teóricos do cinema da época. A segmentação da narração em "sequências", sem preocupação pela continuidade e pelas transiçóes que alongam o texto, o tratamento de cada "cena" pela sucessão de detalhes e pela economia de referências, eram que permitiam a aproximação" (XAVIER, Ismail. Sétima arte, um culto moderno. São Paulo: Perspectiva, 1978: 143). As afirmaçốes de Xavier são plenamente aplicáveis à escrita de Alcântara Machado. 
Ruído. Pó”; "A tabuleta diz: JAVA. Estrepitosamente a orquestra toca La Belote. Música saltitante, tremelicante. Cinquenta, cem, duzentos pares"*; "O francês gordo, suando felicidade, esfrega os bigodes no rosto besuntado da magricela. Imprudência de francês gordo. Bufando como uma Mallet, a mulher de roxo o enfrenta e o esbofeteia. Ao estalo segue-se a descompostura berrada: - Tu ne t'imaginais pas de me rencontrer, hein, salaud?”; “ "Num muro, fronteiro ao baile, cartazes coloridos falam da crise da vida, das eleições municipais, dos atentados comunistas. Um é tremendo: conclamam os padeiros. Truculentamente: OUVRIERS BOULANGERS! NOUS ALLONS FAIRE APPEL À VOTRE COLÈRE!”*

Deixo ao olho do leitor interessado a tarefa de procurar esses e outros motivos do texto na ilustraçáo/tela de Paim Vieira. Quanto ao desenho-relato sobre as peripécias da orquestra, tramado na metade inferior da série de ilustraçôes, ele dá a ver outra narrativa paralela e simultânea que, por um lado, reforça o pacto instaurado desde a capa: o leitor/espectador entrou na sala de cinema ao abrir o livro. Por outro lado, incita a desviar o olhar e seguir os avatares da comédia que aí se desenvolve: o violinista primeiro, o flautista depois, a pianista mais tarde, desertam um após o outro da sessão.

Essa estrutura complexa nos remete a um leitor/espectador familiarizado com as diversas manifestações da cultura visual em ascensão, capaz de circular com fluidez entre vários códigos e convençôes. Ao mesmo tempo, se olharmos para o conteúdo dos planos projetados por essas fitas de papel, ele nos fala de um leitor/ espectador convidado a flanar por paisagens sociais heterogêneas: a Paris do Boulevard des Capucines, dos parques de diversóes ou foires foraines, a Paris do proletariado.

III

1926. O brasileiro Alberto Cavalcanti (1897-1982) realiza Rien que les heures, ${ }^{7}$ um dos primeiros documentários urbanos que

\footnotetext{
${ }^{7}$ A partir de 1922, Cavalcanti participa de diversas experiências associadas à primeira vanguarda cinematográfica francesa: assistente de Marcel L'Herbier em Résurrection (1922) e Feu Mathias Pascal (1924-5); roteirista de L'inondation (1923) de Louis Delluc e montador de Voyage au Congo (1925-6) de Marc Allégret; diretor de Le train sans yeux (1922), com roteiro baseado no romance homônimo de Delluc, de 1919. Todavia, a estreia desse filme somente ocorrerá em 1929, motivo pelo qual Rien que les heures costuma ser considerada sua primeira realização (Cf. PELLIZARI, Lorenzo; VALENTINETTI, Claudio M. Alberto Cavalcanti: Pontos sobre o Brasil. São Paulo: Instituto Lina Bo e P.M. Bardi, 1995: 21)
}

* (MACHADO, Antonio de Alcântara. "1. A flama da saudade". In:__. Pathé Baby (1926), op. cit.: 49.)

*(MACHADO, Antonio de Alcântara. "O baile do magic-city". In: _. Pathé Baby (1926), op. cit.: 50-1.)

* (MACHADO, Antonio de Alcântara. "3. Meia-noite, boulevard des capucines". In: ___ Pathé Baby (1926), op. cit.: 54-5.)

* (MACHADO, Antonio de Alcântara. "4. Meia-noite, rue st. Honoré". In: (1926), op. cit.: 56-7.) 
* (GRIERSON, John. "Postulados del documental" (1932-4). In: ROMANGUERA I RAMIO, Joaquim; ALSINA THEVENET, Homero. Textos y manifiestos del cine. Madrid: Cátedra, 1998: 139-148.) ensaiaram uma composição sinfônica, na opinião de John Grierson. ${ }^{8 *}$ Evidentemente, registros urbanos náo constituem um dado inédito. Nasceram contemporaneamente às primeiras vistas captadas pelo cinematógrafo, medraram nas "atualidades" cinematográficas e primeiros cinejornais. Mas Rien que les heures - precedido por esse hino do imaginário moderno que é Manhatta (1921), de Strand e Sheeler, seguido de imediato por Berlim, a sinfonia de uma grande cidade (1927), de Walter Ruttmann, e, um pouco mais tarde, por O homem da câmera (1929), de Dziga Vertov - é produto de outra conjuntura no que tange ao desenvolvimento do cinema como espetáculo, como produção cultural, como linguagem artística. Se as vistas e atualidades do período inicial assumem para si uma mescla de incumbências informativo-propagandísticas e formativo-pedagógicas solidárias ao ideário positivista modernizador; se podem ser consideradas sucedâneos fílmicos desse artefato chamado notícia, os novos documentários se inserem no contexto das vanguardas. O resgate da imagem "direta", neste caso, se associa intimamente à busca de novas formas e gêneros capazes de se contrapor a um modelo já hegemônico em meados dos anos vinte, à sua lógica de produção, ao star system e aos grandes estúdios dos quais é inseparável, à sua estética e sua moral, àquilo que se consolidou como sua manifestação dominante: o cinema narrativo de ficção, herdeiro, em grande medida, do melodrama e do folhetim. Daí o repúdio às matrizes teatrais e romanescas, o abandono total ou parcial dos atores profissionais, da mise en scène, a fragmentação ou deflação do relato, a supressão dos letreiros - inteiramente ausentes ou reduzidos à sua mínima expressão, embora lhes seja atribuída com frequência uma função capital: ser porta-vozes explícitos de um programa. Se o marco instituído nos livros examinados se orientava para um fora de campo alertando o leitor sobre seus vínculos com o espetáculo cinematográfico e sobre a adoção do cinema como modelo, o marco, aqui, visa instaurar em primeira instância um campo próprio, pois quer definir os atributos de uma linguagem especificamente fílmica (especificidade tensionada de

\footnotetext{
${ }^{8} \mathrm{O}$ uso extensivo do termo adotado por Ruttmann no título de seu filme para referir-se a um conjunto de produçôes de características a princípio análogas aparece cedo nos escritos de John Grierson $(1932,1934)$. Mais recentemente, Vicente Sánchez-Biosca ("Fantasías urbanas en el cine de los años veinte", LARS n. 7, 2007: 23-25) adota a denominação "fantasia" para tratar do mesmo conjunto.
} 
início pela indexalidade inerente às imagens captadas pelo operador, evidentemente).

Transcrevo os seis primeiros intertítulos de Rien que les heures, responsáveis pela formulação de uma espécie de manifesto que será retomado no segmento final do filme (intertítulos vinte e seis e vinte e sete):

1 - Este filme não conta uma história. É tão somente uma sucessão de impressóes sobre o tempo que passa e não pretende ser a sintese de nenhuma cidade.

2 - Todas as cidades seriam iguais se seus monumentos não as distinguissem (Planos da Torre Eiffel, da Porta de Brandemburgo, etc., seguidos da imagem de um losango)

3 - Não a vida mundana e elegante (Plano de mulheres vestidas à moda e com luxo, reunindo-se numa escadaria. A imagem se congela para logo metamorfosear-se num cartaz publicitário violentamente rasgado por uma máo. Plano de pequenos pedaços de papel, resultado da destruição do cartaz. Parecem folhas -de árvores- esparsas no chão)

4 - (mas) A vida cotidiana dos humildes, dos marginados. (Um carro moderno, por sobreimpressão, se metamorfoseia numa carroça a tração animal, conduzida por um homem. A carroça está repleta de grandes sacos. Provavelmente se trata de um catador de lixo. Novamente surge a imagem de um losango)

5 - Os pintores de toda classe vêm à cidade (Primeiríssimo plano de um olho. Sucessão de pinturas - sobre algumas delas, a câmera faz um travelling - à qual se segue um fotograma com as assinaturas de Matisse, Signac, Chagall, Bonnard; Vouillard, Utrillo, Graz, etc., realizadores das pinturas projetadas. Plano com múltiplas bandeiras em miniatura de diversos países. Plano (trucado) de olhos multiplicados ocupando a totalidade da tela).

6 - Mas somente uma sucessão de imagens pode restituir-nos a vida (Primeiro plano de um relógio marcando $24 \mathrm{hs} / 13 \mathrm{hs}$; depois 12/1hs. Plano do sol despontando entre nuvens. Plano em picado de um prédio, numa ruazinha estreita. Um vulto negro caminha pela rua) $)^{9}$

Nem relação (religação), nem sínteses. Nem a ilusão de continuidade e transparência promovida pela montagem clássica, que

\footnotetext{
${ }^{9}$ No filme de Dziga Vertov, de maneira análoga, aos créditos inicias se segue esta advertência: "Atenção espectadores: esta é uma experiência em comunicação cinemática realizada a partir de eventos reais. Sem o auxílio de intertítulos. Sem o auxílio de uma história. Sem o auxílio do teatro. Este trabalho experimental quer criar uma verdadeira linguagem cinematográfica internacional baseada na absoluta separação com respeito à linguagem teatral e literária”.
} 
escamoteia seus cortes os subordinando às linhas de força de um relato conducente a um fim, nem a copresença e a condensação estáticas das artes visuais (sabemos que se trata de uma caracterização falsa e redutora, mas proponho aceitá-la por um momento). Nem história, nem pintura. Tão somente uma sucessão de impressóes, uma série de imagens que visam restituir a vida no que ela tem de instável, móvel, heteróclita, uma sucessão de imagens tendentes a formalizar o transcorrer das horas numa grande cidade que poderia ser "qualquer uma" no referente a seus polos extremos e ao contraponto instaurado: a vida elegante e mundana, a dos marginalizados ("déclassés" no original), matéria privilegiada ainda que não única da visão do cineasta. O espaço-tempo da urbe e os sujeitos que circulam por ela se tornam alvo da objetiva e objeto de montagem. A tarefa assumida explicita sua não completude:

26 - Podemos fixar um ponto no espaço, imobilizar um momento no tempo... (Plano de um globo terráqueo girando rapidamente. Plano próximo focando o setor correspondente a França/Paris, que se funde com uma imagem do Arco de Triunfo, ao que se segue um primeiro plano do relógio e depois de uma máe com sua filha. Novamente o globo terráqueo, agora enfocando Pequim, seguido de fotos e cartôes postais orientais. Plano de um casal, correndo. No fundo, pinturas)

27 - Mas o espaço e o tempo, ambos, fogem à nossa possessão (Globo girando vertiginosamente, imagens cartográficas balançando: Pequim, Paris o Continente Americano. Primeiro plano das agulhas de um relógio em projeção acelerada. A tela/campo do relógio se fragmenta em subcampos, contendo imagens/cenas diversas. Novamente as agulhas do relógio. Fusão de planos de carros, ruas, prédios. Imagem do losango inicial. FIN).

Como a mente-câmera e o regime de percepçôes do qual são solidárias, essas fitas se furtam, programaticamente, às representações totalizantes. Apresentam fragmentos fugidios, instáveis, não integráveis numa direção unívoca. Mas isso significa que se renunciou a traçar itinerários? Suprimiu-se realmente toda feição narrativa? Não é possível conceber Rien que les heures e várias outras sinfonias ou fantasias cinematográficas do período como correlatos cinematográficos da crônica? Antes de esboçar uma resposta se faz necessário um breve desvio. 
Durante as primeiras décadas posteriores à irrupção do cinematógrafo, enquanto o cinema se consolida como espetáculo, consolida seus procedimentos e pleiteia um lugar no espaço da "cultura", a transposição de um repertório literário legitimado ou conhecido é moeda corrente. Também são moeda corrente, é claro, as críticas endereçadas a essa estratégia, em especial à adaptação de peças teatrais. ${ }^{10}$ Mas, à medida que a linguagem fílmica elabora um conjunto de recursos e uma sintaxe "independentes" (a prescindência de letreiros é um dos sintomas dessa autonomia), a crítica e a teoria nascentes se consagram à tarefa de definir seu lugar específico. Entretanto, desde as primeiras reflexões, a constituição do próprio campo se viu obrigada a recorrer a seu exterior: arte nova, "outra", mas ao mesmo tempo de síntese, soma das precedentes, sétima arte, segundo a expressão já canônica de Riciotto Canudo, um dos intelectuais pioneiros em matéria de teorização sobre o discurso cinematográfico. ${ }^{11}$

Em meados dos anos vinte e no âmbito das experiências vanguardistas aqui referidas, a busca do lugar próprio continuará sendo nomeada (invocada) sob o signo do alheio e se manifestará como fuga em direçâo a figuraçôes associadas à esfera do musical (o cinema como sinfonia de imagens), do coreográfico (o cinema como dança de luzes e sombras), do poético (o cinema como lírica visual). As referências musicais e coreográficas expressam a prerrogativa concedida à montagem como operaçẫo estritamente cinematográfica: tempo e ritmo/extensão dos planos concatenados são responsáveis pelo caráter da composição, por suas mudanças de intensidade, seu pathos, pelas sensações suscitadas. A bandeira de uma lírica visual será alçada tanto para reivindicar a poeticidade/fotogenia das imagens diretas em contraposição à estética do estúdio, como para distender ou subverter as imposiçóes do relato clássico e da figuração "realista", graças ao uso de diversos procedimentos (contraponto ou

\footnotetext{
${ }^{10}$ Sobre este tema, cf. meu artigo (GÁRATE, Miriam V. "Tradição letrada e cinema mudo: em torno a algumas crônicas mexicanas de começos do século XX”. Alea. Estudos Neolatinos, vol. 10 , n. 2, 2008: 197-211).

${ }^{11}$ Em seus primeiros escritos Canudo concebe o cinema como um "teatro cinematográfico", para depois suplantar essa noção pela de "arte plástica em movimento" e, posteriormente, pela de fusão das artes do tempo e do espaço. Essa reflexão, que se desenvolve ao longo da década de 1910, culmina no célebre Manifeste des sept arts, de 1921, reelaboraçáo de ideias esboçadas em alguns textos anteriores.
} 
* (CAVALCANTI, Alberto. Filme e realidade. Rio de Janeiro: Livraria Editora da Casa do Estudante do Brasil, 1957: 70.) fusão de planos não convencionais, metáforas, montagens de atrações, etc.). Ora, nesses documentários mais ou menos sinfônicos, mais ou menos líricos, o transcurso de um dia instaura uma espécie de moldura; em todos eles comparece a sequência amanhecer/ manhã/ meio-dia/ tarde/ noite. Ainda que supostamente se tenha renunciado a "contar uma história", a mera existência dessa matriz institui um vetor que orienta o andamento e expressão dos múltiplos planos orquestrados em cada uma das partes. À reunião do heterogêneo operada pelo cronista em cada um de seus textos, e depois impressa ao conjunto de crônicas arquitetadas como uma sessão de cinema/livro, responde (e corresponde) a estruturação desses filmes como percurso por rien que les heures/nada mais que as horas, no espaço urbano. A retórica do passeio ao dia na cidade renarrativiza, portanto, estas realizaçóes, nas quais também se pode ler uma sobre-escrita ou reinscrição da notícia e do jornal.

V

Dentre as personagens que atravessam Rien que les heures, que seguem trilhas paralelas, se tangenciam ou se entrecruzam, destacam-se três figuras femininas. ${ }^{12}$ Nos três casos, trata-se de uma mise en scène que visa se integrar às tomadas diretas e ao mesmo tempo integrá-las entre si, conferindo alguma unidade ao que anos depois Cavalcanti qualificaria como uma espécie de documentário romanesco. * A expressão híbrida evoca uma duplicidade discursiva também presente na crônica jornalística-literária. A rejeição da história expressa no letreiro se modaliza (se matiza) devido à presença dessas figuras que, ao sulcar as horas em várias direçóes, urdem uma trama entrecortada, aberta, múltipla, composta por vários fios, mas não por isso ausente.

A primeira delas é a velha maltrapilha vista do alto ao principiar Rien que les heures, uma figura que reaparece intermitentemente mas com regularidade - vulto cansado, familiar e distante, anônimo apesar da paulatina aproximação que organiza as tomadas, já que,

\footnotetext{
${ }^{12}$ Devido às restrições mencionadas em nota de rodapé precedente, os três fotogramas relativos às personagens não puderam ser reproduzidos no corpo deste trabalho. O filme de Cavalcanti circula amplamente em youtube. A versão circulante corresponde à cópia da George Eastman House. International Museum of Photography and Film of New York. Há também uma cópia da mesma versão disponível em DVD: Experimental cinema: 1922-1954. New York: Kino International, 2009, vol. 3 .
} 
ainda no primeiríssimo plano, que a mostra ao findar o filme, seu rosto permanecerá oculto, velado pelos cabelos em desordem. A segunda é a jovem (La fille) que surge ao Amanhecer, quando um letreiro anuncia os Primeiros trabalhos e que, ao se aproximar - tanto da câmera como do operário que atravessa a calçada carregando uma cesta - se revelará como prostituta. Rejeitada (um close capta de perto seu ar de frustração e de abatimento), passará a integrar mais tarde o contingente das pessoas (que) se esforçam por esquecer $o$ desemprego, como reza outro intertítulo. A terceira mulher é uma vendedora de jornais que irrompe ao anoitecer (Le soir) quando, como sustenta o letreiro que precede sua primeira aparição, o trabalho se interrompe: agora é o tempo do descanso e da diversáo. Não para ela, que precisamente inicia sua jornada e sai para vender periódicos pelas avenidas da cidade: France soir, L'intransigeant, La presse. A sequência mostra um travelling diagonal de recuo, que acompanha o avanço da jovem mulher num ritmo cada vez mais frenético, e cede lugar a uma montagem alternada: os cabeçalhos e manchetes dos jornais, em primeiro plano, giram como um carrossel; a jornaleira avança apregoando as notícias do dia.

$\mathrm{O}$ jogo instaurado pela presença dessas peças-chave da rua - jogo entendido tanto em sua acepção mecânica quanto lúdica, concebido como "desajuste" introduzido pela representação e como simulação livre mas elucidativo - exigiria um exame demorado que excede o propósito deste artigo. Assinalo tão-somente que as figuras da mendiga, da prostituta e da jornaleira implicam per se um descompasso em relação à ordem temporal pautada pelo ideologema do trabalho, bem como embaralham a organização do espaço na bipartição privado/público. Não é impossível que a introdução e privilégio dessas peças situadas nas bordas, nas margens, mas de modo algum fora do campo da dinâmica societária, sejam parcialmente responsáveis pelo "insucesso" que Grierson atribui ao filme de Cavalcanti no que diz respeito à "sensação de marcha necessária ao gênero sinfonia", ${ }^{*}$ efeito que sim teria sido plenamente atingido no filme de Ruttmann. Para além da "insuficiência no domínio da arte da montagem" (Ibidem: 145) e da distância evidente entre uma produção modestíssima e a megaprodução de Berlim, seria necessário ensaiar outras razóes para enxergar as diferenças. Olhada de um certo ângulo, a "marcha” ruttmanniana, de indiscutível destreza formal e técnica, talvez seja mais orgânica e mais solidária em relação ao tempo-espaço instituído pela modernidade compulsória que o
* (GRIERSON, John. "Postulados del documental" (1932-4). In: ROMANGUERA I RAMIO Joaquim; ALSINA THEVENET, Homero. Textos y manifiestos del cine, op. cit.: 145.) 
* (JEANCOLAS, Jean-Pierre "N.V.D. 28, appel à témoins". In: MARCORELLES, Louis, org.; 100 années Lumière: rétrospective de l'oeuvre documentaire des grands cinéastes français de Louis Lumière jusqu'à nos jours. Paris: AFA Intermédia, 1989: 20.)
Recebido em: $15 / 10 / 2013$

Aprovado em: 15/01/2014 descompassado Rien que les heures; talvez o desajuste constitua um sintoma, não necessariamente um defeito.

Volto, para concluir, à sequência final do filme de Cavalcanti protagonizada pela jornaleira e à reinscriçấo deslocada de uma zona do periódico que essa sequência supóe. Terminada a tarefa, a jovem empreende o regresso. Ela envereda, como a maior parte das imagens do filme, para ao subúrbio. O plano a mostra caminhando um pouco distraída e cansada, quando de repente um homem lhe fecha a passagem: o roubo, a resistência (um close da boca aberta convida a escutar seu grito inaudível), o assassinato, tudo aparece concatenado numa sucessão rápida. A jornaleira jaz numa rua estreita. Ironicamente, dois policiais que fazem a ronda habitual lançam um olhar desatento sobre a área, não enxergam nada de estranho e partem em suas bicicletas. $\mathrm{O}$ breve drama que o espectador acaba de assistir torna-se matéria (literalmente, corpo) de uma notícia a ser estampada no jornal do dia prestes a começar - e que desta vez a mulher não apregoará. Essa tematização de um segmento inerente à imprensa moderna - a sessão de policiais - também promove um jogo, um deslocamento de ângulo e de foco: reescreve a notícia a partir de um lugar que mescla a informaçáo, o viés narrativo (a tradição folhetinesca), o olhar do operador. Talvez não seja casual que precisamente nos anos vinte o documentário dê testemunho de um progressivo desenvolvimento da consciência autoral, indiciado na crescente preocupação, antes inexistente, por consignar o nome do cineasta nos créditos. Embora não se equipare à câmera stylo reivindicada pela nouvelle vague dos anos 60 , a primeira nouvelle vague documentaire, ${ }^{*}$ sabe-se longe da linguagem supostamente neutra, impessoal e não marcada do Cine-jornal, sabe estar realizando um exercício de estilo com a matéria que lhe provê a cidade e que o operador revê. Rien que les heures: uma crônica de celuloide?

Miriam V. Gárate é Professora Livre-Docente do Departamento de Teoria Literária, Unicamp. Investiga as relaçóes instauradas entre práticas letradas e cinema na América Latina, durante o período silente. Algumas publicaçóes recentes sobre o tema são "Três escritores vão ao cinematógrafo. Crônica jornalística e retórica da viagem em Luis Urbina, Olavo Bilac e Ramón López Velarde". Revista Caracol (USP), n. 3, 2012; "Soñar con Hollywood desde América Latina. Cine y literatura en algunos relatos de los años veinte y treinta". Cuadernos de Literatura. Pontificia Universidad Javeriana, Bogotá, n. 34, 2013. E-mail: <mgarate@iel.unicamp.br>. 